\title{
FEATURES OF THE PARASITIC SYSTEM FORMATION IN HERBIVOROUS FISH IN THE AQUACULTURE OF THE NORTH-EASTERN AND EASTERN REGIONS OF UKRAINE
}

\author{
Yevtushenko A. V. \\ National Scientific Center 'Institute of Experimental and Clinical Veterinary \\ Medicine', Kharkiv, Ukraine, e-mail: aevt76@gmail.com
}

\begin{abstract}
Summary. The research aimed to determine the peculiarities of the formation of the parasitic system in herbivorous fish in the aquaculture of the North-Eastern and Eastern regions of Ukraine. In fish farms of the North-Eastern and Eastern regions of Ukraine, 26 species of parasites were found in herbivorous fish: 19 species in the silver carp (11 protozoa, 1 - monogeneans, 4 - trematodes, 3 - parasitic crustaceans); 18 species in the grass carp (6- protozoa, 1 - monogeneans, 4 - trematodes, 4 - cestodes, 3 - parasitic crustaceans); and 20 species in the bighead carp (10 protozoa, 1 - monogeneans, 4 - trematodes, 2 - cestodes, 3 - parasitic crustaceans). 11 species (42.3\%) of registered parasites were invasive; 18 species $(69.2 \%)$ of the detected herbivorous fish's parasites develop directly and 8 (30.8\%) with the participation of definitive and intermediate hosts; the fish is an additional (second intermediate) host in the life cycle of 6 species $(23.1 \%)$ of parasites. Outbreaks of diseases caused by parasitic protozoa from the genera Myxobolus, Cryptobia, Chilodonella, and Ichthyophthirius have been reported in both fingerlings and two-year-olds. The protozoa from the genera Ichthyobodo, Trichodina, and Trichodinella were registered en masse only in fingerlings. Pathogens from the genus Dactylogyrus were more often registered among three-year-old silver and bighead carps. Metacercariae of Ichthyocotylurus variegatus were found en masse in fingerlings of the grass carp. Posthodiplostomum cuticola larvae in unfavorable farms were found with a high level of prevalence in fish of different age groups. Thong plerocercoids were more commonly recorded in two-year-old silver and bighead carps and fingerlings of the grass carp. The highest level of cestode infection with Bothriocephalus acheilognathi was recorded in fingerlings of the grass carp. Parasitic crustaceans Sinergasilus lieni with a high level of prevalence were registered in two-year-old and three-year-old fish. Crustaceans Lernaea cyprinacea massively affected two-year-old and three-year-old fish. Pathogens from the genera Trichodina, Cryptobia, and Chilodonella, and Dactylogyrus hypophthalmichthys, Posthodiplostomum cuticola, and Sinergasilus lieni were of the greatest epizootic significance for the silver carp; for the bighead carp - from the genus Myxobolus, (especially M.pavlovskii), Chilodonella piscicola, Ichthyophthirius multifiliis, Dactylogyrus aristichthys, Posthodiplostomum cuticola, Diplostomum spathaceum, Digramma interrupta, and Sinergasilus lieni; for the grass carp Bothriocephalus acheilognathi, Ichthyocotylurus variegatus, Ligula intestinalis, Sinergasilus major, Lernaea cyprinacea, Ichthyobodo necator, and Ichthyophthirius multifiliis
\end{abstract}

Keywords: parasitic system, protozoa, helmints, parasitic crustaceans, herbivorous fish, aquaculture

Introduction. The main objects of aquaculture in Ukraine are herbivorous fish: the silver carp Hypophthalmichthys molitrix (Valenciennes, 1844), the bighead carp - Hypophthalmichthys nobilis (Richardson, 1845), and the grass carp - Ctenopharyngodon idella (Valenciennes, 1844). This is a group of fish from the Far Eastern complex, which was acclimatized in the reservoirs of Ukraine in the second half of the $20^{\text {th }}$ century. In addition to their industrial significance, these fish species are the improvers of water bodies, and their range of food (except for the bighead carp) is not competitive with other native species.

Herbivorous fish larvae are obtained only by the factory method - by incubating the eggs in special devices. This is due to the lower water temperature in the reservoirs of Ukraine than in the basins of the Amur, the Ussuri, and the Songhua River - the natural habitats of these species of fish.

Seeds from the broodstock begin to ripen at a temperature of $21-22^{\circ} \mathrm{C}$. The broodstock is injected with pituitary hormones for the simultaneous maturation of eggs and milk. Eggs selected from females are fertilized with male milk in special containers and transferred to incubators. After hatching, the larvae are transferred into fry (growth) ponds. In autumn, fingerlings are transferred into the winter ponds, and after winter - in the spring, fingerlings are transferred into feeding ponds (Vovk, 1976).

Fish stocking material was first imported to Ukraine from the Far East in 1954 (Vovk, 1976). Prior to its introduction parasitic fauna of herbivorous fish counted 23 pathogen species (Davydov et al., 2011). A number of these parasites have spread significantly and disease outbreaks have begun to cause significant economic damage to fish farms.

In addition, herbivorous fish have been found to be highly susceptible to some species of local parasites, pathogens of such diseases as diplostomosis, digramosis, postodiplostomosis, ligulosis, etc. (Davydov et al., 2005, 2011; Musselius, 1969). A similar picture was registered during the acclimatization of herbivorous fish in other countries (Beretar', 2009; Lysenko, 2003, 2004). 
The monograph 'Ecology of Fish Parasites in WaterBodies of Ukraine' (Davydov et al., 2011) contains more than 200 scientific papers devoted to the study of species diversity of herbivorous fish's parasites in aquatic ecosystems of Ukraine. Along with this, data on the current epizootic status of water bodies in the aquaculture of the North-Eastern and Eastern regions of Ukraine are missing.

The aim of the research was to determine the peculiarities of the formation of the parasitic system in herbivorous fish in the aquaculture of the North-Eastern and Eastern regions of Ukraine. In this regard, the following tasks were set: to study the species composition of parasites, to determine the level of infection of fish, to study the age dynamics of infection, to identify epizootically significant species of parasites that can cause disease outbreaks and fish death.

Materials and methods. Fifteen specimens of each fish species and age groups were studied in a specialized laboratory of the National Scientific Center 'Institute of Experimental and Clinical Veterinary Medicine' (Kharkiv, Ukraine). Ichthyological material was taken in different seasons of the year from spawning, growing, feeding, and wintering ponds in specialized fish farms, as well as agricultural ponds of Kharkiv, Sumy, Poltava, and Donetsk regions.

Ichthyological analysis was performed by the method of incomplete helminthological autopsy according to Bykhovskaya-Pavlovskaya (1985) and Markevich (1951). Species affiliation of parasites was determined by the 'Keys to Parasites of Freshwater Fish of the Fauna of the USSR' (Bauer, 1984, 1985, 1987).

Prevalence of infection (PI, \%) was determined by the formula:

$$
P I=\frac{x}{y} \times 100 \%
$$

where: $\mathrm{x}-$ the number of fish in which parasites were found; $y$ - the total number of studied fish.

Statistical processing of the obtained results was carried out following the recommendations on biometrics using the parametric Student's $t$-test (Van Emden, 2019).

Results and discussion. According to the results of the research (Table 1), 19 species of parasites were found in the silver carp: 11 species (59.7\%) of protozoa, 1 (5.3\%) monogeneans, $4(21.0 \%)$ - trematodes, 3(15.8\%) parasitic crustaceans; 20 species of parasites were registered in the bighead carp: 10 species $(50.0 \%)$ of protozoa, $1(5.0 \%)$ - monogeneans, $4(20.0 \%)-$ trematodes, $2(10.0 \%)$ - cestodes, $3(15.0 \%)$ - parasitic crustaceans; and 18 species of parasites were recorded in the grass carp: 6 species (33.3\%) of protozoa, $1(5.6 \%)-$ monogeneans, $4(22.0 \%)$ - trematodes, $4(22.0 \%)-$ cestodes, $3(16.7 \%)$ - parasitic crustaceans.
In total, 26 species of parasites were found in herbivorous fish, of which 11 species (42.3\%) are invasive.

It should be noted that 18 species $(69.2 \%)$ of the detected herbivorous fish's parasites develop directly and $8(30.8 \%)$ - with the participation of definitive and intermediate hosts. The fish is an additional (second intermediate) host in the life cycle of 6 species (23.1\%) of parasites.

Representatives of the genus Dactylogyrus are specific parasites to their hosts: in the case of the silver carp only D. hypophthalmichthys was registered, in the grass carp D. ctenopharyngodonis, and in the bighead carpD. aristichthys. Representatives of parasitic crustaceans from the genus Sinergasilus showed species specificity too: $S$. lieni was registered in the silver carp and the bighead carp, and S. major in the grass carp.

It is important to note that in the silver carp coupled with the bighead carp, 15 species (68.2\%) of the detected pathogens are parasites on the surface of the body, skin and gills; one species is a parasite of the intestinal mucosa, one species - a parasite of the eyes, one species - the subcutaneous tissue, three species - the abdominal cavity.

In the grass carp, 11 species $(61.1 \%)$ were found to be parasites on the surface of the body, skin and gills; one species were parasites of the eyes, three species - the abdominal cavity, and two species - the intestine. M. ellipsoides was localized in all organs and tissues of the three species.

According to the results of studying the age dynamics of infection of herbivorous fish with pathogens of protozooses, the data shown in Fig. 1 were obtained.

Thus, the data in Fig. 1 show that outbreaks of diseases caused by parasitic protozoa were recorded mainly in this fingerlings and two-year-old fish. It should be noted that the highest level of PI by microsporidia was recorded in fingerlings and two-year-old fish. At the same time, PI M. pavlovskii in fingerlings reached $89 \%$, in two-yearolds $-78 \%$, the level of infection of three-year-olds and four-year-olds was much lower - $14 \%$ and $11 \%$, respectively.

The prevalence of $M$.drjagini and $M$. ellipsoides in two-year-olds was $14 \%$ and $20 \%$, three-year-olds - $9 \%$ and $12 \%$, fingerlings $-3 \%$ and $8 \%$, respectively. A similar pattern was registered in the E. sinensis infection: PI in two-year-olds was $12 \%$, three-year-olds - $8 \%$, fingerlings $-3 \%$. Another picture was observed when infecting fish with pathogens of ciliaphorosis - T. acuta, T. nigra, T. epizootica: the highest level of infestation was recorded in fingerlings - $81 \%, 58 \%, 19 \%$, and the infection in two-year-olds was much lower $-22 \%, 14 \%$, $4 \%$, respectively. 
Table 1 - Species composition of herbivorous fish's parasites and places of their localization in the conditions of aquaculture of the North-Eastern and Eastern regions of Ukraine

\begin{tabular}{|c|c|c|c|c|c|}
\hline \multirow[b]{2}{*}{ No. } & \multirow[b]{2}{*}{ Parasite species } & \multirow[b]{2}{*}{ Localization } & \multicolumn{3}{|c|}{ Fish species } \\
\hline & & & $\begin{array}{l}\text { Silver } \\
\text { carp }\end{array}$ & $\begin{array}{l}\text { Bighead } \\
\text { carp }\end{array}$ & $\begin{array}{l}\text { Grass } \\
\text { carp }\end{array}$ \\
\hline 1 & ${ }^{*}$ Cryptobia branchialis (Nie in Chen, 1956$)$ & gills & + & + & - \\
\hline 2 & Ichthyobodo necator (= Costia necatrix) (Henneguy, 1883) & gills, skin & + & + & + \\
\hline 3 & ${ }^{*}$ Eimeria sinensis Chen, 1956 & intestine & + & + & - \\
\hline 4 & ${ }^{\star}$ Myxobolus pavlovskii (Achmerov, 1954) & gills & + & + & - \\
\hline 5 & ${ }^{\star}$ Myxobolus drjagini (Achmerov, 1954) & subcutaneous tissue & + & + & - \\
\hline 6 & Myxobolus ellipsoides Thélohan, 1892 & all organs and tissues & + & - & + \\
\hline 7 & Chilodonella piscicola (Zacharias, 1894) Jankowski, 1980 & gills, body surface & + & + & + \\
\hline 8 & Ichthyophthirius multifiliis Fouquet, 1876 & gills, body surface & + & + & + \\
\hline 9 & Trichodina acuta Lom, 1961 & gills, body surface & + & + & + \\
\hline 10 & Trichodina nigra Lom, 1961 & gills, body surface & + & + & - \\
\hline 11 & Trichodinella epizootica (Raabe, 1950) Sramek-Husek, 1953 & gills, body surface & + & + & + \\
\hline 12 & ${ }^{\star}$ Dactylogyrus hypophthalmichthys Achmerov, 1952 & gills & + & - & - \\
\hline 13 & ${ }^{\star}$ Dactylogyrus aristichthys Long et Yu, 1958 & gills & - & + & - \\
\hline 14 & ${ }^{\star}$ Dactylogyrus ctenopharyngodonis Achmerov, 1952 & gills & - & - & + \\
\hline 15 & Diplostomum spathaceum (Rudolphi, 1819) mtc & eyes & + & + & + \\
\hline 16 & Posthodiplostomum cuticola (Nordmann, 1832) mtc & skin & + & + & + \\
\hline 17 & $\begin{array}{r}\text { Ichthyocotylurus variegatus (= Tetracotyle variegate) } \\
\text { (Creplin, 1825) Odening, } 1969 \mathrm{mtc}\end{array}$ & abdomen & + & + & + \\
\hline 18 & Apophallus donicus (Skrjabin et Lindtrop, 1919) mtc & body surface, fins, gills & + & + & + \\
\hline 19 & ${ }^{\star}$ Khawia sinensis Hsü, 1935 & intestine & - & - & + \\
\hline 20 & ${ }^{\star}$ Bothriocephalus acheilognathi Yamaguti, 1934 & intestine & - & - & + \\
\hline 21 & Ligula intestinalis (Linnaeus, 1758) 1 & abdomen & - & + & + \\
\hline 22 & Digramma interrupta (Rudolphi, 1810) l & abdomen & - & + & + \\
\hline 23 & * Sinergasilus lieni Yin, 1949 & gills & + & + & - \\
\hline 24 & ${ }^{\star}$ Sinergasilus major (Markevich, 1940) & gills & - & - & + \\
\hline 25 & Lernaea cyprinacea Linnaeus, 1758 & skin & + & + & + \\
\hline 26 & Argulus foliaceus (Linnaeus, 1758) & skin & + & + & + \\
\hline
\end{tabular}

Remarks: ${ }^{\star}$ - invasive species, mtc - metacercariae, 1 - larvae.

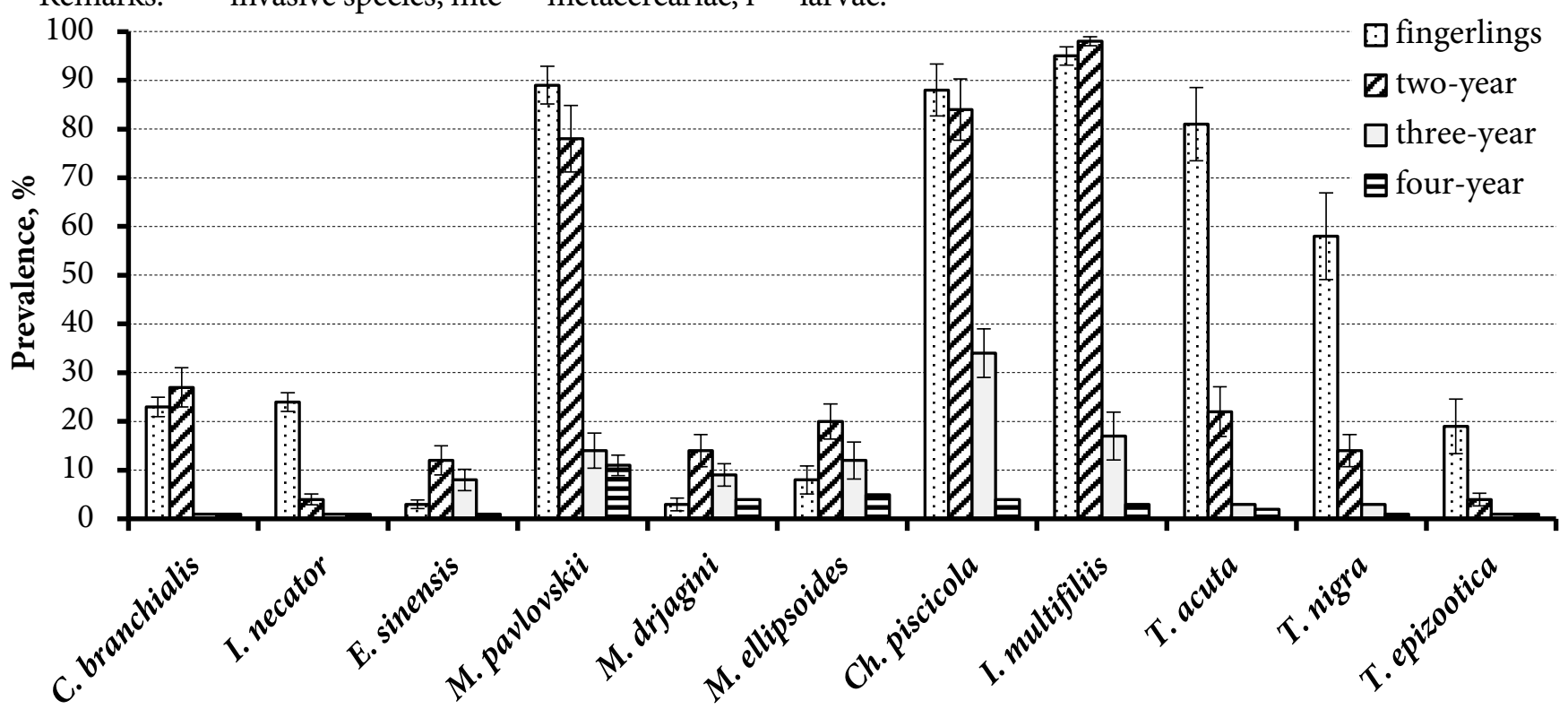

Figure 1. Age dynamics of infection of herbivorous fish with pathogens of protozooses during outbreaks of diseases in fish farms of the North-Eastern and Eastern regions of Ukraine 
Outbreaks of protozoozes caused by other parasitic ciliates - Ch. piscicola and I. multifiliis were accompanied by high levels of infection in both fingerlings - $88 \%, 95 \%$ and two-year-olds - $84 \%, 98 \%$, respectively. As for the pathogens of mastigophorosis, a high level of prevalence of I. necator was registered in fingerlings $-24 \%$, and the pathogen C. branchialis was detected with a fairly high level of infection in fish both fingerlings (23\%) and twoyear-olds (27\%). Infection of four-year-olds with the protozoa was significantly reduced and turned into a form of parasite carriage.

When studying the seasonal dynamics of infection of fish with protozoa, it was found that the peak level of infection of the silver carp with parasites from the genera Trichodina and Trichodinella was registered in August, the protozoa of the genus Cryptobia - in August-September. Outbreaks of ichthyoftiriosis infection (I. multifiliis) were most often recorded in the conditions of significant fish density that occurred in early summer when fry were in spawning ponds (when growing young) or in autumn among fish of different ages after transferring into winter ponds (under the conditions of autumn temperature rise). The highest level of infection of fish with chylodonels (Ch.piscicola) was recorded in winter ponds from October to April.

Outbreaks of disease depended on water temperature, the optimal value for the development of these parasites ranged from $5^{\circ} \mathrm{C}$ to $18^{\circ} \mathrm{C}$. Infection of young silver carp with myxosporidia (M. pavlovskii, M. ellipsoides, M. drjagini) was registered from the first days of their placing in growing ponds and an increase in intensity was observed throughout the warm period of the year. The highest level of infection of both fingerlings and two-yearold silver carp was registered at the beginning of the winter period. The death of the bighead carp from myxobolic parasitemia was sometimes observed.

Thus, according to the results of the conducted researches it was established that the pathogens from the genera Trichodina and Cryptobia, to a lesser extent Chilodonella, had the greatest epizootic significance for the silver carp. Representatives of the genus Myxobolus, especially M. pavlovskii, which caused outbreaks among fingerlings and two-year-olds, proved to be epizootically important species for the bighead carp. Ch. piscicola and I. multifiliis were also of epizootic significance. In the grass carp, protozoa were found mainly in the form of parasite carriage with a slight level of prevalence, but outbreaks caused by I. necator and I. multifiliis have been reported.

The level of infection of the silver carp coupled with the bighead carp with pathogens of helminthiasis and crustaceosis in outbreaks of the diseases in fish farms in the North-Eastern and Eastern regions of Ukraine is shown in Fig. 2. Pathogens from the genus Dactylogyrus were more frequently registered among three-year-olds with a maximum level of $D$. hypophthalmichthys infection in the silver carp $-74 \%$ and $D$. aristichthys in the bighead carp $-54 \%$.

Metacercariae of Diplostomum spathaceum were more often registered in two-year-old fish - 34\%, less often in fingerlings (22\%) and three-year-olds (15\%). P. cuticola larvae in unfavorable farms were found with a high level of prevalence in fish of different age groups: PI of twoyear-olds $-81 \%$, three-year-olds - $54 \%$, fingerlings $38 \%$.

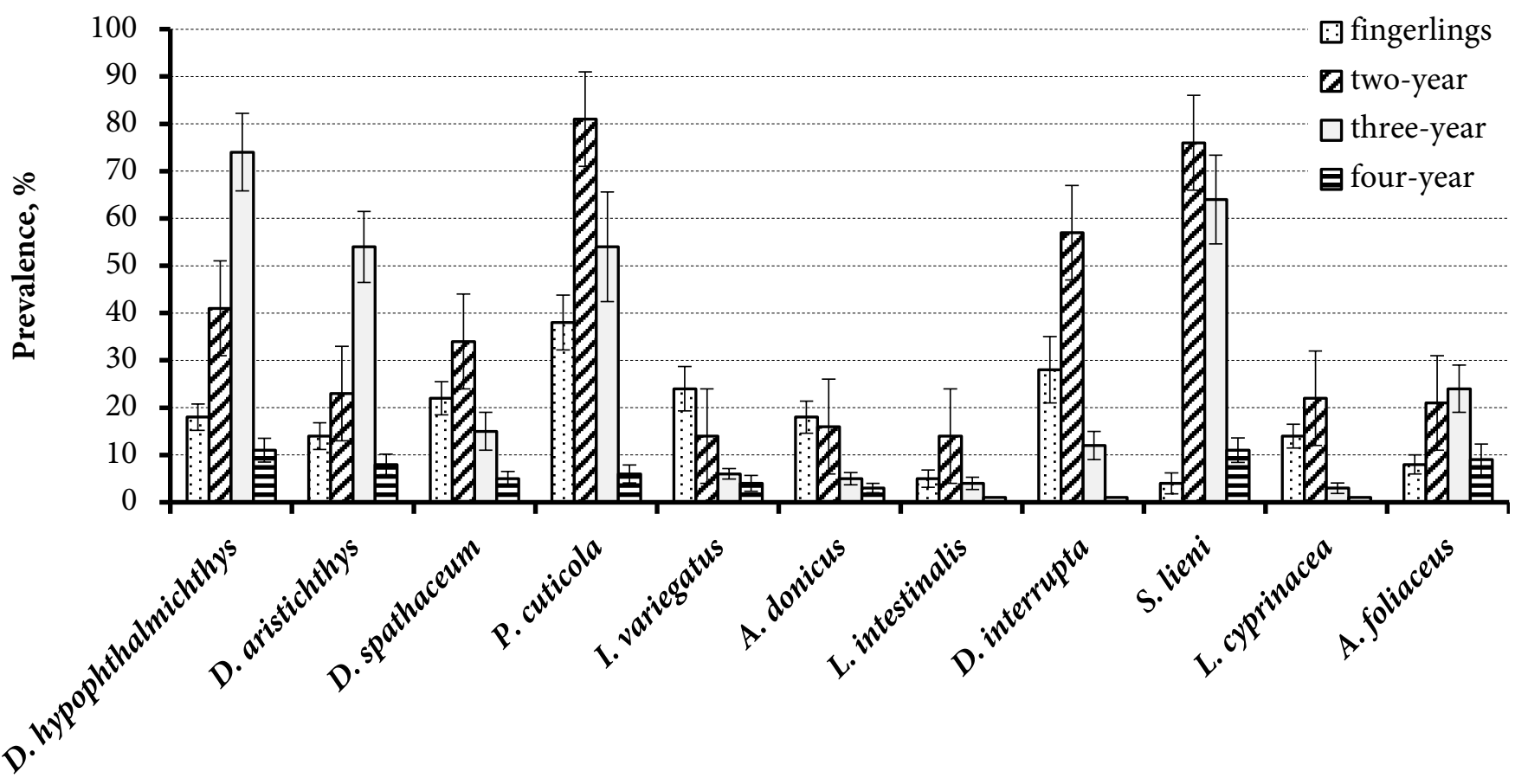

Figure 2. Age dynamics of infection of the silver carp and the bighead carp with helminthic and crustacean pathogens in disease outbreaks in fish farms in the North-Eastern and Eastern regions of Ukraine 
Similar dynamics of infection was observed when infected with metacercariae of I. variegatus and A. donicus $-24 \%$ and $18 \%$ in fingerlings, $14 \%$ and $16 \%$ in two-year-olds, and it significantly reduced in older fish. Thong plerocercoids in outbreaks of ligulidosis were also more common registered among two-year-olds: PI with L. intestinalis - $14 \%$, PI with D. interrupta $-57 \%$.

Parasitic crustaceans S. lieni with a high level of prevalence were registered in two-year-old and three- year-old fish $-76 \%$ and $64 \%$, respectively. L. cyprinacea was more often found among two-year-olds (PI - 22\%) and fingerlings $(\mathrm{PI}-14 \%)$. A. foliaceus were registered among fish of different age groups: $\mathrm{PI}$ in fingerlings $-8 \%$, two-year-olds $-21 \%$, three-year-olds $-24 \%$, four-yearolds $-9 \%$.

The age dynamics of infection of the grass carp with pathogens of helminthiasis and crustaceasis is shown in Fig. 3.

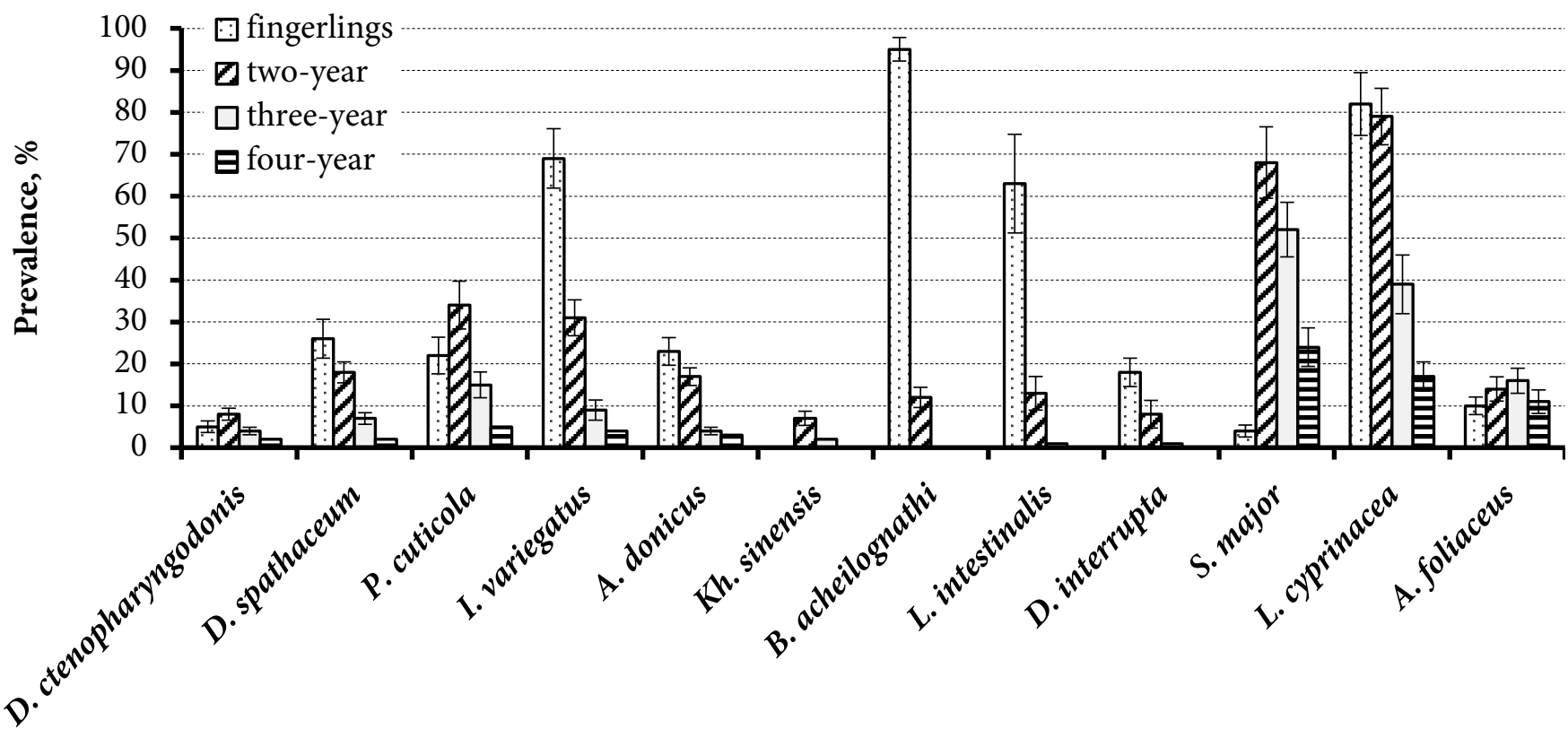

Figure 3. Age dynamics of infection of the grass carp with helminthic and crustacean pathogens in disease outbreaks in fish farms in the North-Eastern and Eastern regions of Ukraine

Parasitic fauna and the level of infection of the grass carp differed slightly from other herbivorous fish species. Thus, monogeneans D. ctenopharyngodonis were registered with a low level of infection in fish of all age groups (PI in fingerlings - 5\%, two-year-olds - 8\%, three-year-olds - 4\%). Metacercariae of I. variegatus were found en masse in fingerlings of the grass carp with PI $69 \%$, the lowest level of prevalence was registered in twoyear-olds and three-year-olds $-31 \%$ and $9 \%$, respectively.

A similar pattern of dynamics of infection was observed when infected with metacercariae of trematodes D. spathaceum and A.donicus - $26 \%$ and $23 \%$ in fingerlings, and $18 \%$ and $17 \%$ in two-year-olds, respectively.

Metacercariae of $P$. cuticola were more often registered in two-year-olds (PI - 34\%), less often in fingerlings (PI - 22\%) and three-year-olds (PI - 15\%). Pleguercoids ligulide were registered mainly in fingerlings (PI with L. intestinalis $-63 \%, D$. interrupta $-18 \%$ ) and two-yearolds (PI with L. intestinalis - 13\%, D. interrupta - 8\%).

Infection with B. acheilognathi in fingerlings reached $95 \%$, while prevalence of two-year-olds did not exceed $12 \%$, and in older fish helminths were not detected. It should be noted that Kh. sinensis with PI of $7 \%$ and $2 \%$, respectively, were found in two-year-old and three-yearold grass carp.

Compared with other herbivorous fish species, the grass carp was more often affected by crustaceans L. cyprinacea. The PI in fingerlings and two-year-olds reached 825 and 79\%, and the level of infection of threeyear-olds and four-year-olds was $39 \%$ and $17 \%$, respectively. A high level of infection with crustaceans S. major was registered. Thus, the PI in fingerlings was insignificant $(4 \%)$, but in older fish it reached $68 \%$ in twoyear-olds, $52 \%$ in three-year-olds, $24 \%$ in four-year-olds. The level of A. foliaceus infection in fish of different age groups almost did not differ and ranged from 10\% in fingerlings to $16 \%$ in three-year-olds.

According to the analysis of seasonal dynamics of infection of fish with helminthiasis and crustacean pathogens, it was found that monogeneans in fingerlings of the silver carp began to be registered in July, the maximum level of infection of fish regardless of age was observed in late July-August, with decreasing the water temperature prevalence decreased.

Pathogens of postodiplostomosis were registered in fish throughout the year, but the highest level of infection was observed in the autumn. During the winter, 
prevalence decreased slightly, but began to increase again during the summer. When infected with metacercariae of D. spathaceum, I. variegatus, and A. donicus, the peak level of infection was also observed in autumn, but during the winter period prevalence did not decrease significantly. Infection with plerocercoids ligulide (L. intestinalis, D. interrupta) occurred throughout the summer and in late autumn prevalence was the highest. Due to the death of fish weakened by pathogens during the winter, the level of prevalence decreased significantly in the spring.

A similar pattern was observed in the infection of the grass carp with pathogens of botryocephallosis, but the peak of the infection was observed in late summer-early autumn. The highest level of infection with parasitic crustaceans from the genera Sinergasilus and Lernaea was recorded throughout the summer period with the maximum level of prevalence in September. Crustaceans A. foliaceus were recorded on fish throughout the year.

Therefore, based on the results of research, it was found that monogeneans D. hypophthalmichthys, metacercariae of P. cuticola, S. lieni have a veterinary-sanitary (epizootic) significance in aquaculture for the silver carp, for the bighead carp - D. aristichthys, P. cuticola, D. spathaceum, D. interrupta, S. lieni, for the grass carp - B. acheilognathi, I. variegatus, L. intestinalis, S. major, L. cyprinacea.

According to Davydov et al. (2012) modern fauna of herbivorous fish's parasites in reservoirs of Ukraine is represented by 83 species. At the same time, about 20 species of invasive species of parasites have survived, including 11 species of protozoa (C. branchialis, Eimeria mylopharyngodoni, Myxidium ctenopharyngodonis, Sphaerospora amurensis, Sphaerospora cyprini, Myxobolus dispar, Myxobolus latus, M.drjagini, M. ellipsoides, Balantidium ctenopharyngodoni, Thrichodina nobilis), four species of monogeneans (D. ctenopharyngodonis, Dactylogyrus lamellatus, D. hypophthalmichthys, Gyrodactylus ctenopharyngodontis), three species of cestodes (Biacetabulum appendiculatus, Kh. sinensis, B. acheilognathi), two species of trematodes (Amurotrema dombrovskajae, Sanguinicola skrjabini), one species of crustaceans (S. lieni). Other parasites are native species that have been transmitted to herbivorous fish from native ichthyofauna.

According to our data, 26 species of parasites were found in herbivorous fish, of which 11 species are invasive.

It should be noted that the fauna of herbivorous fish's parasites differs in different regions of Ukraine. According to Katiukha and Vozniuk (2016), only pathogens of diplostomosis and sinergasillosis in the silver carp and only pathogens of lerneosis in the grass carp were found in the aquaculture of Rivne Region.

The obtained results on the age and seasonal dynamics of infection allow the introduction of a set of treatment and prevention measures in the control of pathogens (Dunn and Hatcher, 2015). Thus, to control monogeneans and parasitic crustaceans, it is recommended to take preventive measures at the beginning of the growing season in June among fish of all ages.

Double treatment of fish with larval cestodes and trematodes is recommended - in July and September among fingerlings and two-year-olds. In intestinal cestodes, the most effective treatment period is AugustSeptember. Preventive treatment of fish of all ages with parasitic protozoa should be carried out after transferring fish into winter ponds.

Conclusions. 1. In fish farms of the North-Eastern and Eastern regions of Ukraine, 26 species of parasites were found in herbivorous fish: 19 species in the silver carp (11 - protozoa, 1 - monogeneans, 4 - trematodes, 3 - parasitic crustaceans); 18 species in the grass carp (6- protozoa, 1 - monogeneans, $4-$ trematodes, $4-$ cestodes, 3 - parasitic crustaceans); and 20 species in the bighead carp (10 - protozoa, $1-$ monogeneans, 4 - trematodes, 2 - cestodes, 3 - parasitic crustaceans). 11 species $(42.3 \%)$ of registered parasites were invasive; 18 species (69.2\%) of the detected herbivorous fish's parasites develop directly and $8(30.8 \%)$ - with the participation of definitive and intermediate hosts; the fish is an additional (second intermediate) host in the life cycle of 6 species (23.1\%) of parasites.

2. Outbreaks of diseases caused by parasitic protozoa from the genera Myxobolus, Cryptobia, Chilodonella, and Ichthyophthirius have been reported in both fingerlings and two-year-olds. The protozoa from the genera Ichthyobodo, Trichodina, and Trichodinella were registered en masse only in fingerlings. Pathogens from the genus Dactylogyrus were more often registered among threeyear-old silver and bighead carps. Metacercariae of Ichthyocotylurus variegatus were found en masse in fingerlings of the grass carp. Posthodiplostomum cuticola larvae in unfavorable farms were found with a high level of prevalence in fish of different age groups. Thong plerocercoids were more commonly recorded in twoyear-old silver and bighead carps and fingerlings of the grass carp. The highest level of cestode infection with Bothriocephalus acheilognathi was recorded in fingerlings of the grass carp. Parasitic crustaceans Sinergasilus lieni with a high level of prevalence were registered in two-yearold and three-year-old fish. Crustaceans Lernaea cyprinacea massively affected two-year-old and threeyear-old fish.

3. Pathogens from the genera Trichodina, Cryptobia, and Chilodonella, and Dactylogyrus hypophthalmichthys, Posthodiplostomum cuticola, and Sinergasilus lieni were of the greatest epizootic significance for the silver carp; for the bighead carp - from the genus Myxobolus, (especially M. pavlovskii), Chilodonella piscicola, Ichthyophthirius multifiliis, Dactylogyrus aristichthys, Posthodiplostomum cuticola, Diplostomum spathaceum, Digramma interrupta, and Sinergasilus lieni; for the grass carp - Bothriocephalus 
acheilognathi, Ichthyocotylurus variegatus, Ligula intestinalis, Sinergasilus major, Lernaea cyprinacea, Ichthyobodo necator, and Ichthyophthirius multifiliis.

Prospects for further research. The obtained results will help to increase the effectiveness of control of the epizootic situation, will allow more rapid and effective implementation of anti-epizootic measures, will justify the development of more effective treatment and prevention measures, which will improve the quality and safety of fishery products.

\section{References}

Bauer, O. N. (ed.) (1984) Keys to Parasites of Freshwater Fish of the Fauna of the USSR. Volume 1. Parasitic Protozoa [Opredelitel' parazitov presnovodnykh ryb fauny SSSR. Tom 1. Paraziticheskie prosteyshie] (3 vols). Leningrad: Nauka. [in Russian].

Bauer, O. N. (ed.) (1985) Keys to Parasites of Freshwater Fish of the Fauna of the USSR. Volume 2. Parasitic Metazoa (Chapter 1) [Opredelitel' parazitov presnovodnykh ryb fauny SSSR. Tom 2. Paraziticheskie mnogokletochnye (Pervaya chast')] (3 vols). Leningrad: Nauka. [in Russian].

Bauer, O. N. (ed.) (1987) Keys to Parasites of Freshwater Fish of the Fauna of the USSR. Volume 3. Parasitic Metazoa (Chapter 2) [Opredelitel' parazitov presnovodnykh ryb fauny SSSR. Tom 3. Paraziticheskie mnogokletochnye (Vtoraya chast')] (3 vols). Leningrad: Nauka. [in Russian].

Beretar', I. M. (2009) 'Parasite fauna of the silver carp in pond farms of Krasnodar Territory' [Parazitofauna belogo tolstolobika $\mathrm{v}$ prudovykh khozyaystvakh Krasnodarskogo kraya], Veterinariya Kubani, 5, pp. 14-16. Available at: https://www. elibrary.ru/item.asp?id=21279012. [in Russian].

Bykhovskaya-Pavlovskaya, I. Ye. (1985) Fish Parasites [Parazity ryb]. Leningrad: Nauka. [in Russian].

Davydov, O. N., Bazeev, R. E., Kurovskaya, L. Ya. and Temnikhanov, Yu. D. (2005) 'Changes in helminth number during introduction of herbivorous fish into Kiev water basin' [Izmeneniya chislennosti gel'mintov pri introduktsii rastitel'noyadnykh ryb v Kievskom vodokhranilishche], Vestnik zoologii. Supplement, 19(1), pp.96-97. Available at: http://ma il.izan.kiev.ua/vz-pdf/suppl/Supplement\%202005-19-1.pdf. [in Russian].

Davydov, O. N., Neborachek, S. I., Kurovskaya, L. Ya. and Lysenko, V. N. (2011) Ecology of Fish Parasites in Water-Bodies of Ukraine [Ekologiya parazitov ryb vodoemov Ukrainy]. Kiev. ISBN 9789660262348. [in Russian].

Davydov, O. N., Kurovskaya, L. Ya., Neborachek, S. I. and Lysenko, V. N. (2012) 'Parasitofauna of phytophagous fishes in some cultivation regions' [Parazitofauna rastitel'noyadnykh ryb $\mathrm{v}$ nekotorykh regionakh kul'tivirovaniya], Fisheries Science of Ukraine [Rybohospodarska nauka Ukrainy], 3-4, pp. 136-148. Available at: http://nbuv.gov.ua/UJRN/rnu_2012_3-4_30. [in Russian].
Dunn, A. M. and Hatcher, M. J. (2015) 'Parasites and biological invasions: Parallels, interactions, and control', Trends in Parasitology, 31(5), pp. 189-199. doi: 10.1016/j.pt.2014.12. 003.

Katiukha, S. M. and Vozniuk, I. O. (2016) 'Spreading of parasitic diseases of fishes in the ponds of the Rivne Oblast' [Poshyrennia invaziinykh khvorob ryb u vodoimakh Rivnenskoi oblasti], Veterinary Biotechnology [Veterynarna biotekhnolohiia], 28, pp. 94-101. Available at: http://nbuv.gov.ua/UJRN/vbtb_ 2016_28_12. [in Ukrainian].

Lysenko, A. A. (2003) 'Associated diseases of pond fishes in intensive fish-farming' [Assotsiativnye zabolevaniya prudovykh ryb pri intensivnom ryborazvedenii], Veterinary [Veterinariya], 12 , pp. 32-34. Available at: https://www.elibrary.ru/item.asp?id= 16895268. [in Russian].

Lysenko, A. A. (2004) 'Associated diseases of fish during breeding in pond farms of the Krasnodar Territory' [Assotsiativnye zabolevaniya ryby pri razvedenii $\mathrm{v}$ prudovykh khozyaystvakh Krasnodarskogo kraya], Proceedings of the Kuban State Agrarian University [Trudy Kubanskogo gosudarstvennogo agrarnogo universiteta], 406(434), pp. 57-61. [in Russian].

Markevich, A. P. (1951) Parasite Fauna of Freshwater Fish of the Ukrainian SSR [Parazitofauna presnovodnykh ryb Ukrainskoy SSR]. Kiev: Publishing House of the Academy of Sciences of Ukrainian. [in Russian].

Musselius, V. A. (1969) 'Parasites of phytophagous fish from the Far East cultivated in ponds of the European part of the USSR' [Parazity rastitel'noyadnykh ryb dal'nevostochnogo kompleksa pri vyrashchivanii $\mathrm{v}$ prudovykh khozyaystvakh Evropeyskoy chasti SSSR], Parazitologiya, 3(3), pp. 236-243. Available at: https://www.zin.ru/journals/parazitologiya/content /1969/prz_1969_3_8_Musselius.pdf. [in Russian].

Van Emden, H. F. (2019) Statistics for Terrified Biologists. $2^{\text {nd }}$ ed. Hoboken, NJ: John Wiley \& Sons. ISBN 9781119563679.

Vovk, P. S. (1976) Biology of Far Eastern Herbivorous Fish and Their Economic Use in Water Bodies of Ukraine [Biologiya dal'nevostochnykh rastitel'noyadnykh ryb i ikh khozyaystvennoe ispol'zovanie $v$ vodoemakh Ukrainy]. Kiev: Naukova dumka. [in Russian]. 